\title{
Private Schools in Canada and the USA: Contrasts and Commonalities
}

\author{
Derek J. Allison \\ The University of Western Ontario \\ Deani Neven Van Pelt \\ Fraser Institute
}

\author{
Sazid Hasan \\ Fraser Institute
}

\author{
Lynn Bosetti \\ La Trobe University
}

Characteristics of private schools in Canada and the USA are compared using NCES Private School Universe Survey data, previously unavailable Canadian data, and selected survey results from PISA 2015. Differences are noted between curriculum levels, average enrollments, religious orientations and school autonomy. Five Canadian provinces offer direct funding to private schools whereas various US states channel funds to private schools through voucher or similar schemes. While the proportion of students attending private schools in Canada has been increasing, the growth of charter schools in the US appears to have contributed to a decline in US private school enrollments.

When people think of independent schools, they have, I think, a stereotype of a very small number of very elite kinds of schools where all of the students are named Chatsworth Osborne, Jr., where the teachers are eccentrics, and everybody has more money than God.

Peter Gow, as quoted by David Cutler (2015).

What are private schools really like? How could we know? Like all other social realities, private —or as they are also known, independent—schools defy easy portrayal. They can only be truly known by living in them. But we can only live within or visit just one at a time, leaving the many others in the world to be known only by association, projection, reputation-or statistics. We can, for instance, count or lookup how many private schools there are in a given area, how many students they enroll, their average class size, how many declare a religious identity, and so forth. This is an admittedly limited way of knowing, but it does allow us to gain an informed appreciation of otherwise elusive phenomena spread across space and time, beyond direct experience. Indeed, 'statistics' comes to us from the new Latin statisticum, meaning 'of the state,' the enumeration of socio-economic resources and activities being indispensable in the administration of nations. Which is why modern states and pan-national agencies collect, compare and analyze the statistics needed to "see"- to lay hold of, as Max Weber had it-the social entities and 
processes with which they are concerned. And which is why, if we wish to know more about privateindependent schools we can collect or consult previously compiled descriptive statistics. Indeed, this is the only feasible way to compare similar social phenomena, such as private schools, in different places, such as the USA and Canada, as is attempted in this essay.

The topic has intrinsic interest if only because private-independent schools tend to be poorly understood, with stereotypical conceptions such as captured in the epigraph, tending to prevail. Such conceptions not only misrepresent the great majority of non-government schools, as they can also be called, they can fail to appreciate the not inconsiderable numbers of citizens they educate and the often substantial financial and other investments made by parents and other supporters. Various interesting questions also arise on more theoretical planes. Are systematic differences evident between private and public schools in each country? Do, for example, individual private schools characteristically enroll more or less students than public schools in each country? More generally, are Canadian private schools more similar to public schools in Canada or to private schools in the USA? The equifinality postulate in systems theory suggests it is reasonable to suppose so by predicting that open systems of the same kind, such as private schools, tend toward similar mature states (Bertalanffy, 1969).

Canada is roughly a tenth of the demographic and economic size of the USA. The first section of the paper takes stock of such contextual differences that necessarily exert broad constraints on education in each country. The second section considers the organization and operation of education in the two countries with specific attention to public schools and schooling. The United States, for example, spends a higher proportion of national wealth on primary and secondary education, but Canada's PISA rankings exceed those of the USA.

The third and major section of the paper draws on recent descriptive statistics to compare aspects of private schools in the two countries, with specific attention to identity, location and size. In rough accord with the substantial population differences, there are almost fourteen times as many private schools in the USA as Canada but, taken overall, Canadian private schools are larger, and fewer are religious in character.

Improving access to non-government-operated schools is a central aim of school choice proponents. In some conceptions, particularly in Canada, school choice is largely equated with improved access to private schools (Allison, 2015; Allison \& Van Pelt, 2012). Developments in the USA have provided families with greater school choice through increased access to public-private hybrid options, especially charter schools. The final section briefly compares government policies within the two countries aimed at improving access to private schools by providing financial support. Clear differences are evident in the two countries, with those Canadian provinces which support access to private schools choosing to provide enrollment-driven financial aid to qualifying schools, while US states offer various forms of conditional financial aid to support access to private schools.

\section{DISPARATE COMPANIONS}

Taken together, Canada and the United States of America account for 14 percent of the world's land area, 4.9 percent of its population and a stunning 36 percent of its total wealth (Credit Suisse 2016, Table 2-4; World Bank, 2017). Yet, as summarized in Table 1, there are marked imbalances between the national resources of the two countries.

Even though their land areas are remarkably similar, the relative extent of their inhabited lands is not: two of three Canadians live within 100 kilometers of the US border, with the majority concentrated in metropolitan areas in the four most populous provinces of, in order of population, Ontario, Quebec, British Columbia and Alberta, leaving almost all of northern Canada unsettled, and substantial areas in the mid-north and central regions sparsely populated. This settlement pattern is reflected in the proportion of agricultural land, which is more than six times greater in the USA. Still, virtually identical proportions of Canadians and Americans live in rural and urban neighborhoods, although the ways these are defined

and measured in the two countries vary, making precise comparison hazardous. Some 46 percent of Canadians and 45 percent of Americans reside in metropolitan areas with populations in excess of one 
million. Overall, four fifths of all Canadians and Americans live in urban areas, but settlement in the US is spread more widely across the land than in Canada.

TABLE 1

CANADA AND THE USA: SELECTED COMPARISONS

\begin{tabular}{|c|c|c|}
\hline & Canada & $\underline{\mathrm{USA}}$ \\
\hline Land area sq km. (2016) & $9, \overline{984,700}$ & $9,83 \overline{1,500}$ \\
\hline$\%$ agricultural (2014) & $7.2 \%$ & $44.6 \%$ \\
\hline Total population (2016) & $36,286,425$ & $323,127,513$ \\
\hline$\%$ rural $(2015)$ & $18 \%$ & $18 \%$ \\
\hline$\%$ urban $(2015)$ & $82 \%$ & $82 \%$ \\
\hline$\%$ urban pop larger than one million (2016) & $46 \%$ & $45 \%$ \\
\hline Median age (2015) & 42.0 & 37.9 \\
\hline $0-14$ age cohort ( $\%$ of total), 2016 & $16 \%$ & $19 \%$ \\
\hline $15-64$ age cohort ( $\%$ of total), 2016 & $67 \%$ & $66 \%$ \\
\hline $65+$ age cohort $(\%$ total $), 2016$ & $17 \%$ & $15 \%$ \\
\hline Age dependency ratio (2016) & $48 \%$ & $52 \%$ \\
\hline Annual population growth rate (2016) & $1.2 \%$ & $0.7 \%$ \\
\hline Fertility rate (births per 1,000 women), 2015 & 1.6 & 1.8 \\
\hline Net migration (2012) & $1,145,721$ & $4,500,000$ \\
\hline Net migration rate (net migration/total pop) & $3.2 \%$ & $1.6 \%$ \\
\hline \multicolumn{3}{|c|}{ Self-declared identity (Statistics Canada, 2017 \& US Census Bureau, 2016) } \\
\hline White (CA="non-visible person") & $77.7 \%$ & $77.1 \%$ \\
\hline Black $(\mathrm{CA}=$ visible minority 2011$)$ & $3.5 \%$ & $13.3 \%$ \\
\hline Asian (CA= "South Asian \& Chinese") & $10.2 \%$ & $5.6 \%$ \\
\hline Aboriginal (US= “American Indian / Alaska Native") & $4.8 \%$ & $1.2 \%$ \\
\hline Not represented in above categories & $3.8 \%$ & $2.8 \%$ \\
\hline Language spoken at home (Statistics Canada, 2015a \& & English $66.3 \%$ & English $79.2 \%$ \\
\hline \multirow[t]{2}{*}{ Ryan, 2013) } & French $21.0 \%$ & Spanish $12.9 \%$ \\
\hline & Other $12.6 \%$ & Other $7.9 \%$ \\
\hline Declared religion (Statistics Canada, 2016) \& Pew & Christian $67.3 \%$ & Christian $70.5 \%$ \\
\hline \multirow[t]{5}{*}{ Research Center, 2015). CA=2011, US=2014 } & [Catholic $38.9 \%$ ] & [Catholic 20.8\% ] \\
\hline & Muslim 3.2\% & Muslim $0.9 \%$, \\
\hline & Jewish $1 \%$ & Jewish $1.9 \%$ \\
\hline & other $4.6 \%$ & other $3.2 \%$ \\
\hline & none $23.9 \%$ & none $22.8 \%$ \\
\hline GDP per capita (current USD), 2016 & $\$ 42,157.9$ & $\$ 57,466.8$ \\
\hline Total labor force unemployed (2014) & $7.1 \%$ & $4.9 \%$ \\
\hline \multicolumn{3}{|l|}{ GDP Contribution by sector (CIA, 2016) } \\
\hline Agriculture (farming, forestry, etc.) & $1.6 \%$ & $1.1 \%$ \\
\hline Industry (manufacturing, mining, etc.) & $28.2 \%$ & $19.4 \%$ \\
\hline Services (governance, finance, education, etc.) & $70.3 \%$ & $79.5 \%$ \\
\hline Tax revenue (\% of GDP, USD, 2015 (OECD, 2016a) & $30.8 \%$ & $26.4 \%$ \\
\hline Net wealth, 2016 billions USD (Credit Suisse, 2016) & $\$ 2,469$ & $\$ 42,344$ \\
\hline Net wealth per adult, 2016, USD (Credit Suisse, 2016) & $\$ 108,464$ & $\$ 206,116$ \\
\hline
\end{tabular}

The American population is also considerably larger, as well as wealthier, more fertile and younger. Currently, there are approximately nine times as many Americans as Canadians, but there were ten times 
as many fifty years earlier. As shown in Table 1, the US has a somewhat higher fertility rate, Canada's higher rate of population growth being attributable - perhaps surprisingly - to higher net migration. These demographic dynamics also contribute to the higher median age of Canada's population and the smaller 0-14 age cohort, and thus a relatively smaller school age population. This pattern, in turn, results in a higher age dependency ratio in the US, which has 52 age defined dependents for every 100 residents of working age, compared to 48 dependents per 100 in the working-aged cohort in Canada. The statistic captures the implied dependency burden based on the age cohorts compared rather than actual economic dependency. In both Canada and the USA a high proportion of youth continue full-time education into their twenties and increasing numbers of people remain gainfully employed after age 65 .

Canada collects census data on visible minorities rather than "race". Findings from the 2016 census (Statistics Canada, 2017) found 77.7 percent of the population did not identify with one of the designated visible minority categories, implying that this represents the proportion of the population that would otherwise be classified as "white". The more direct approach in the US census reported a "White alone" component of 77.1 percent in 2015 (US Census Bureau, 2016). As further summarized in Table 1, the Canadian population includes a much smaller proportion of self-identified Black individuals (3.5\%) than in the US (13.3\%), but larger proportions of Asian (10.2\%) and Aboriginal (4.8\%) peoples than in the US (5.6\% and $1.2 \%$ respectively).

English is by far the dominant language in both countries, although there is a higher proportion of English speakers in the US population (79.2\%) than in Canada's $(66.3 \%)$. French is the second most frequently spoken home language in Canada (21\%), Spanish in the US (12.9\%). French and English are designated as official languages in Canadian law, which has ramifications for education. There are no nationally designated official languages in the USA.

Christianity remains the majority religion in each country with more than two thirds of the respective populations declaring an association with a Christian religion. Even so, a substantially higher proportion of Canadians are self-declared Catholics $(38.9 \%)$ than is the case in the USA $(20.8 \%)$. There is also a higher proportion of Muslims in Canada (3.2\%) than the US $(0.9 \%)$, while there are proportionally twice as many Jewish adherents in the US $(1.9 \%)$ as Canada $(1 \%)$. Somewhat less than a quarter of the population of each country declares no religious affiliation.

The almost $\$ 18.5$ trillion of gross domestic production in the USA in 2016 was slightly over twelve times the value of Canadian GDP in US currency. When the substantial population disparity between the countries is factored in, the relative size of the US economy shrinks to being 1.4 times larger than Canada's. Credit Suisse (2016) identifies the US as the wealthiest country in the world with a total net wealth, defined as "marketable value of financial assets plus non-financial assets (principally housing and land) less debts" (p. 5) of $\$ 84.8$ trillion, accounting for a full third of the world's total wealth; Canada was ranked $8^{\text {th }}$ with a total wealth of $\$ 7.6$ trillion, representing a far more modest three percent of global wealth. Switzerland and Australia were nonetheless ranked first and second in terms of total net worth per adult, the US ranking third and Canada ninth on this adjusted measure. Wealth and income are distributed more unequally in the US than in Canada, the wealthiest ten percent in each country owning more than three quarters of national wealth in the US (77.6\%) compared to more than half $(57.8 \%)$ in Canada (Credit Suisse, 2016, Table 6-5). The OECD Gini coefficients for disposable income in 2013 stood at 0.396 for the US and 0.32 for Canada. To aid in interpretation, the highest Gini coefficient in the OECD data series from which these values were taken was 0.556 (China), the lowest was 0.244 (Iceland). The coefficient for Germany was 0.292 and for the UK 0.358 (OECD Data, 2016a).

Canadian governments at all levels (federal, provincial \& municipal) extract a higher proportion of GDP in taxes $(30.8 \%$ in 2015$)$ than do US governments $(26.4 \%$ in 2015). These tax rates compare to an OECD average of 34.3 percent of GDP in 2015. The Canadian rate was slightly greater than the OECD average at the beginning of this century, but has slowly decreased; the US rate has consistently been below the OECD average over the past half century (OECD Data, 2016b). 


\section{EDUCATION}

Table 2 compares selected aspects of education in Canada and the USA. The substantially larger population of the US dominates many of the education statistics, but there are notable differences in the details. The total enrollment numbers shown include pupils attending both public and private primary and secondary schools. Both countries have a little more than 90 percent of their students enrolled in public schools. On average, public schools account for 82.1 percent of all primary and secondary enrollments in 32 OECD countries (OECD, 2012). For context, Turkey had the highest proportion of students enrolled in public schools (99.2\%), Belgium the smallest (30.5\%), followed by Netherlands $(34 \%)$ and Ireland $(38.5 \%)$.

TABLE 2

EDUCATION IN CANADA AND THE USA: SELECTED COMPARISONS

\begin{tabular}{|c|c|c|}
\hline & Canada & $\underline{\mathrm{USA}}$ \\
\hline Total school enrollment $(2013 / 14)^{1}$ & $5, \overline{093,927}$ & $54,620 \overline{932}$ \\
\hline Public school enrollment $(2013 / 14)^{2}$ & $4,725,210$ & $50,044,522$ \\
\hline$\%$ public enrollment $(2013 / 14)^{1}$ & $92.7 \%$ & $91.6 \%$ \\
\hline Legislative jurisdictions & 10 & 51 \\
\hline Public school districts ${ }^{3}$ & 354 & 13,491 \\
\hline Mean students per district ${ }^{1}$ & 12,933 & 3,710 \\
\hline Public schools ${ }^{4}$ & 16,500 (est.) & 98,271 \\
\hline Mean students per public school ${ }^{1}$ & 286 (est.) & 509 \\
\hline \multicolumn{3}{|l|}{2015 PISA data from survey schools with $15 \mathrm{yr}$ old students } \\
\hline$\%$ immigrant students, all schools ${ }^{5}(S E)$ & $30.1 \%(1.3)$ & $23.1 \%(1.5)$ \\
\hline Fully certified teachers, public schools ${ }^{6}(S E)$ & $95.2 \%(1.3)$ & $94.0 \%(1.4)$ \\
\hline Class size, public schools ${ }^{6}(S E)$ & $26.1(0.2)$ & $26.2(.04)$ \\
\hline Instructional time / week, public schools ${ }^{6}(S E)$ & $27.0 \mathrm{hrs}(0.2)$ & $27.7 \mathrm{hrs}(0.2)$ \\
\hline Index of school autonomy, public schools ${ }^{6}(S E)$ & $64.0(0.8)$ & $79.4(1.8)$ \\
\hline Annual per student public expenditures USD PPP ${ }^{7}$ & $\$ 12,967(2012)$ & $\$ 15,720(2013)$ \\
\hline Public \& private expenditure on education as percent $\mathrm{GDP}^{7}$ & $6.1 \%(2012)$ & $6.2 \%(2013)$ \\
\hline Primary \& secondary expenditure as percent public spending ${ }^{7}$ & $8.8 \%(2012)$ & $8.2 \%(2013)$ \\
\hline \multicolumn{3}{|l|}{ Initial source of public funds for primary \& secondary education: ${ }^{7}$} \\
\hline Central (Federal) government & $4 \%$ & $10 \%$ \\
\hline Provincial / State governments & $76 \%$ & $39 \%$ \\
\hline Local governments & $21 \%$ & $50 \%$ \\
\hline Cumulative expenditure per student K-12, USD $\mathrm{PPP}^{7}$ & $\$ 123,788$ & $\$ 138,692$ \\
\hline \multicolumn{3}{|l|}{ PISA results all schools: Mean score $(S E)$, OECD rank $^{8}$} \\
\hline Reading (2015) & $527(2.3) 1^{\text {st }}$ & $497(3.4) 20^{\text {th }}$ \\
\hline Math (2015) & $516(2.3) 5^{\text {th }}$ & $470(3.2) 31^{\text {st }}$ \\
\hline Science $(2015)$ & $528(2.1) 4^{\text {th }}$ & $496(3.2) 19^{\text {th }}$ \\
\hline $35-44$ year-olds with tertiary education ${ }^{5}$ & $60.6 \%$ & $47.2 \%$ \\
\hline \multicolumn{3}{|l|}{${ }^{1}$ Internal calculations } \\
\hline \multicolumn{3}{|l|}{2 Statistics Canada (2015b) \& NCES (2015a) } \\
\hline \multicolumn{3}{|l|}{3 Canadian Education Association (2015) \& NCES (2015b). } \\
\hline \multicolumn{3}{|c|}{${ }^{4}$ Unreferenced data in Council of Ministers of Education, Canada (2016), \& NCES (2016c). } \\
\hline \multicolumn{3}{|c|}{${ }^{5}$ OECD (2016b): Immigrant students, Table 1.7.1: Percent $35-44$ year-olds with tertiary educa } \\
\hline \multirow{2}{*}{\multicolumn{3}{|c|}{$\begin{array}{l}{ }^{6} \text { OECD (2016c). Fully certified teachers, Table II.6.12; Class size in language of instruction class, Table II.6.30; } \\
\text { Instructional time per week, Table II.6.26; Index of school autonomy, Table II.4.5; }\end{array}$}} \\
\hline & & \\
\hline \multicolumn{3}{|c|}{$\begin{array}{l}\text { Instructional time per week, Table II.6.26; Index of school autonomy, Table II.4.5; } \\
{ }^{7} \text { OECD (2016a) Annual expenditure Table B1.1: Percent GDP Table B2.1: Percent public expenditure Table B4.1: }\end{array}$} \\
\hline \multicolumn{3}{|c|}{ Source of funds by government level Table B4.3: Cumulative expenditure Table B1.3 } \\
\hline \multicolumn{3}{|c|}{$\begin{array}{l}{ }^{8} \text { OECD (2016b) Reading, Table I.4.3: Math, Table I,5.3: Science, Table I.2.3. Ranks for } 35 \text { OECD countries only, } \\
\text { calculated from table data. }\end{array}$} \\
\hline
\end{tabular}


Authority over education is assigned to the 10 provincial legislatures in Canada and the 50 state legislatures plus the District of Columbia in the USA. Each legislature has assigned operational authority over publicly governed, funded and managed education to locally elected or appointed school boards and their bureaucracies. The 354 Canadian school boards each deliver education to an average of almost 13,000 students, while the far more numerous US boards provide education to less than 4,000 students on average. There is obviously considerable variation in the sizes of school districts across each country. Even so, more than two thirds (70.7\%) of US school districts enrolled 2,500 or fewer students in 2013/14 (NCES, 2015b). Comparable data are not available for Canada as a whole, but only 11 percent of school boards in the most populous province of Ontario enrolled fewer than 2,500 students in 2013 (Ontario, 2016). Ontario has the largest school districts in Canada as a result of several waves of district consolidation, but all other provinces have also moved to larger districts in recent decades.

This pattern is reversed in the case of public schools themselves. Whereas the US has almost forty time the number of school districts as does Canada, it has only six times as many public schools, mean school enrollment being markedly higher in the US (509) than Canada (286). US survey data report an actual mean enrollment for all US public schools in 2012/13 of 522 students, with 30 percent of schools enrolling fewer than 300 pupils (NCES, 2014). Again, comparable data for Canada are lacking, but Ontario public schools enrolled an average of 412 students in 2013/14, with 44 percent of these schools enrolling fewer than 300 pupils (Ontario, 2016). In sum, while Canadian school districts are much larger on average, the average US public school enrolls notably more pupils than its Canadian counterpart.

The internal school data shown in Table 2 are from the published responses to the background student and principal questionnaires completed as part of the 2015 Programme for International Student Assessment (PISA) surveys (OECD 2016b/c). Fifteen-year old students in both public and private schools were sampled, but the data reported for private schools in Canada suggests they may not have been adequately represented. An important consequence of the study design is that the school characteristics reported are limited to schools enrolling 15 year old students and are thus not representative of all schools.

The higher proportion of immigrant students in Canadian public and private schools conforms to the higher proportion of immigrants in the population at large as reported in Table 1. Canadian public schools were reported as having a higher proportion of fully certified teachers in public schools than were US public schools, both countries exceeding the OECD average of 84.3 percent. Average class size and total instructional time per week in public schools were both slightly higher in the US than Canada. Instructional time in the sampled schools in both countries was shorter than the OECD average of 26.9 hours per week, and average class sizes equivalent to the OECD average of 26.1.

Values for the OECD index of school autonomy shown in Table 2 represent the proportion of governance tasks ${ }^{1}$ which public school principals completing the 2015 PISA questionnaires considered to be primarily the responsibility of school level actors. Higher values signify higher levels of school autonomy (OECD, 2016c p.151). With a mean score of $64.0(S E=0.79)$ Canadian public schools enrolling 15 year olds fall significantly below the OECD public school mean of $68.1(S E=0.22)$, ranking $19^{\text {th }}$ of 32 OECD countries. In contrast, US public schools scored significantly above the OECD mean, ranking $10^{\text {th }}$. This autonomy gap likely reflects the difference in average school district sizes and concomitant differences in the centralized practices within and across districts.

Various input estimates for the national systems are shown in the central panel of Table 2. The USA spends around 19 percent more per pupil on public and private primary and secondary education than does Canada, a little more as a proportion of GDP, but less as a proportion of total public spending. Annual differences in spending produce a more substantial difference over pupils' school careers, as shown by the almost $\$ 15,000$ USD cumulative difference in per pupil spending between Canada and the US over the years from Grade 1 to Grade 12. Both countries spend more than the OECD average $(\$ 121,898)$ on this measure, Canada only slightly so. Neither country approaches the highest spending nations of Luxembourg $(\$ 247,822)$ and Switzerland $(\$ 231,497)$. Differences in the shares of expenditure across levels of government reflect an important difference in Federal policy involvement in the two countries. Canada is the only OECD country that does not have a national department of education, the 
federal government playing only a minimal role in primary and secondary education. Direct federal funding is limited to shared cost programs negotiated with the provinces to promote instruction in the minority official language and to transfers to fund aboriginal schools. The US federal government has adopted a much more extensive program of targeted funding primarily aimed at improving education for disadvantaged social groups. Over recent decades Canada's provincial governments have assumed an increasing proportion of public school funding, culminating the notable disparity in Provincial and State government shares shown in Table 1. This development has served to further erode the independence of local school boards in Canada.

Selected output indicators are shown in the lower panel of Table 2. The United States' 2015 PISA scores in each of Reading, Mathematics and Science were significantly lower than those for Canada. Canada also has a markedly higher proportion of middle-aged adults with a tertiary level of education; both countries comfortably surpass the OECD average (37.5\%) on this measure, Canada ranking highest of 35 OECD countries.

\section{PRIVATE SCHOOLS}

Table 3 compares selected aspects of private schools in Canada and the USA. The table and the text below draw on three chief sources of data. The latest Private School Universe Survey report from the National Centre for Education Statistics (Broughman \& Swaim, 2016) was the prime source of descriptive data for US private schools in 2013/14. The recently completed Fraser Institute study (Allison, Hasan \& Van Pelt, 2016) provided the main source of descriptive data on Canadian private schools in 2013/14. The Fraser study was encouraged by and partially modeled on the NCES Private School Universe studies to generate previously unavailable Canadian data which would allow several direct comparisons between private schools in the two countries. Unlike the NCES surveys the Fraser study was not based on questionnaire generated survey data but on disaggregated official statistics from the provinces and attributed characteristics for the population of Canadian private schools. Schools were identified by requesting lists of private schools and their grade by grade enrollments in the 2013/14 academic year from the provincial authorities. Additional information was then sought by visiting individual school web sites and consulting publicly accessible membership lists of religious organizations and private school associations. Almost fifteen percent (14.7\%) of schools either did not have websites or the provided addresses were inaccessible. In those cases appropriate information was sought through web searches and indirect sources. Finally, results from the 2015 PISA surveys (OECD, 2016b/c) are used to make direct comparisons between private schools enrolling 15 year old pupils in the two countries and the equivalent measures for public schools reported in Table 2.

In 2013/14 the United States had twelve and a half times as many primary and secondary students receiving their education in private schools as Canada, but seventeen times as many private schools. On average, then, US private schools were smaller than those in Canada, enrolling an average of 136 compared to 191 pupils per school.

This size difference reflects a higher proportion of characteristically smaller elementary level private schools in the US. Whereas elementary schools accounted for 44.3 percent of private schools in Canada in 2013/14 and 28.2 percent of private school enrollments, they constituted 67.1 percent of private schools in the US and almost half (47.1\%) of all private school enrollments. More than two thirds $(37.3 \%)$ of Canadian private schools enrolling almost half (48.3\%) of all private school students offered some combination of elementary and secondary level grades, while only a quarter of US private schools, enrolling 36.8 percent of students offered combined programs. This pattern and the overall size difference carries over into the distribution of schools and students across the size categories shown in Table 3. Almost half $(48.3 \%)$ of private schools in the US enrolled fewer than 50 students compared to a little over a third (38.1\%) in Canada. In contrast, there were almost twice as many schools with 500 or more students in Canada (9.9\%) as the US (5.5\%). With regard to enrollment shares across the six size categories, Canada had more schools in all categories except the smallest. 
Private schools in both countries are notably smaller than public schools, especially in the US where, drawing on Table 2, public schools enroll more than three and a half times as many students on average as private schools. Canadian public schools are closer to one-and-a-half times larger than Canadian private schools on average. As noted earlier, 30 percent of US public schools and 44 percent of Ontario public schools enroll fewer than 300 pupils. In the case of private schools, a staggering 87 percent of US establishments enrolled fewer than 300 students in 2013/14, as did a similar 83 percent of their Canadian counterparts. This general pattern also extends across OECD countries, the mean size of public schools enrolling 15 year olds in the 2015 PISA surveys standing at 767 pupils $(S E=5.9)$ as compared to 615 pupils $(S E=17.7)$ in private schools. In short, private schools are typically smaller than public schools, with US private schools being markedly smaller than those in Canada and other OECD countries on average.

TABLE 3

PRIVATE SCHOOLING IN CANADA AND USA, 2013/14

\begin{tabular}{|c|c|c|}
\hline & Canada & $\underline{\mathrm{USA}}$ \\
\hline Total school enrollment $(2013 / 14)^{1}$ & $5, \overline{093,927}$ & $54 \overline{620,932}$ \\
\hline Private school enrollment $(2013 / 14)$ & 368,717 & $4,576,410$ \\
\hline$\%$ private school enrollment ${ }^{1}$ & $7.2 \%$ & $8.4 \%$ \\
\hline Number of private schools (2013-14) & 1,935 & 33,619 \\
\hline Mean students per private school & 191 & 136 \\
\hline Program levels & \multicolumn{2}{|c|}{ (\% total schools / \% enrollment / mean size) } \\
\hline Elementary & $44.3 \% / 28.2 \% / 121.7$ & $67.1 \% / 47.1 \% / 95.7$ \\
\hline Secondary & $18.4 \% / 23.5 \% / 240.3$ & $8.0 \% / 16.1 \% / 273.1$ \\
\hline Combined & $37.3 \% / 48.3 \% / 247.8$ & $25.0 \% / 36.8 \% / 200.2$ \\
\hline Size category & \multicolumn{2}{|c|}{ (\% total schools / \% total enrollment) } \\
\hline Less than 50 & $38.1 \% / 4.6 \%$ & $48.3 \% / 7.0 \%$ \\
\hline $50-149$ & $27.0 \% / 13.1 \%$ & $23.0 \% / 15.4 \%$ \\
\hline $150-299$ & $17.5 \% / 19.7 \%$ & $15.9 \% / 24.9 \%$ \\
\hline $300-499$ & $7.5 \% / 15.4 \%$ & $7.3 \% / 20.5 \%$ \\
\hline $500-749$ & $4.4 \% / 13.9 \%$ & $3.3 \% / 14.7 \%$ \\
\hline 750 or more & $5.5 \% / 33.3 \%$ & $2.2 \% / 17.5 \%$ \\
\hline Identity & \multicolumn{2}{|c|}{ (\% total schools / \% total enrollment) } \\
\hline Religious & $48.6 \% / 48.3 \%$ & $68.7 \% / 78.7 \%$ \\
\hline Catholic & $8.4 \% / 15.3 \%$ & $19.9 \% / 41.3 \%$ \\
\hline Other & $40.2 \% / 33.0 \%$ & $48.8 \% / 37.4 \%$ \\
\hline Secular & $51.4 \% / 51.7 \%$ & $31.3 \% / 21.3 \%$ \\
\hline Montessori & $9.3 \% / 5.1 \%$ & $8.2 \% / 2.2 \%$ \\
\hline Special Education & $6.1 \% / 2.7 \%$ & $5.5 \% / 2.4 \%$ \\
\hline Other & $36.0 \% / 43.9 \%$ & $17.6 \% / 16.7 \%$ \\
\hline Location & \multicolumn{2}{|c|}{ (\% total schools / \% total enrollment) } \\
\hline Urban / suburban & $68.9 \% / 82.4 \%$ & $67.6 \% / 83.1 \%$ \\
\hline Town & $9.0 \% / 6.8 \%$ & $8.6 \% / 6.1 \%$ \\
\hline Rural & $22.1 \% / 10.8 \%$ & $23.8 \% / 10.8 \%$ \\
\hline \multicolumn{3}{|c|}{2015 PISA data from survey schools with $15 y$ old students ${ }^{2}$} \\
\hline Fully certified teachers $(S E)$ & $90.0 \%(5.6)$ & $65.3 \%(11.1)$ \\
\hline Class size $(S E)$ & $28.5(1.0)$ & $20.3(2.0)$ \\
\hline Mean instructional time, $(S E)$ & $27.0 \mathrm{hrs}(0.4)$ & $28.9 \mathrm{hrs}(0.6)$ \\
\hline Index of school autonomy, $(S E)$ & $78.4(5.9)$ & $95.6(2.9)$ \\
\hline
\end{tabular}




\begin{tabular}{lrr}
\hline Funding $^{3}$ & & \\
Jurisdictions providing financial support & 5 & 31 \\
$\quad$ through grants to private schools & 5 & 0 \\
$\quad$ through voucher / scholarship programs & 0 & 61 \\
OECD gov dependent private schools & $33.4 \%$ & $0 \%$ \\
Private sch students benefitting from funding & $194,983(53 \%)$ & $940,000(20.5 \%)$ est. \\
Jurisdictions with charter school legislation & 1 & 44 \\
Students attending charter schools & $8,732(0.002 \%)$ & $2,519,065 \quad(5.1 \%)$ \\
\hline
\end{tabular}

Sources: Unless otherwise noted, Allison, Hasan, \& Van Pelt (2016) for Canada and Broughman \& Swaim (2016) for the USA.

${ }^{1}$ Internal calculations $\quad{ }^{2} \operatorname{OECD}(2016 \mathrm{~b}) \quad{ }^{3}$ US data from Ed Choice (2016)

Perhaps the most striking contrasts between the two countries concern the religious identity of private schools. Almost half (48.6\%) of Canadian private schools enrolling an almost identical proportion of students $(48.3 \%)$ have a religious orientation, compared to more than two thirds $(68.7 \%)$ of US private schools enrolling more than three quarters $(78.7 \%)$ of private school students. A lion's share of this difference is accounted for by Catholic schools, which accounted for just 15.3 percent of Canadian private school students, compared to a substantial 41.3 percent of private school students in the USA.

This considerable national difference is largely accounted for by the Catholic separate schools that form part of the public school systems in the Canadian provinces of Alberta, Ontario and Saskatchewan. Enrolments in Catholic separate schools in these three provinces totaled 826,324 students in 2012/13, dwarfing the relatively meager numbers of Canadian students enrolled in religious private schools in general $(178,119)$, and Catholic private schools in particular $(56,268)$ (Van Pelt, Clemens, Brown \& Palacios, 2015, Table 3).

If all students attending Canada's Catholic separate schools were educated in private schools, the total number of students attending private schools in Canada would approach 1.3 million, and the proportion of private school students attending religiously oriented private schools would approximate 85 percent, comfortably exceeding the comparable 78.7 percent in the USA. If such a hypothetical situation did obtain, not all students currently attending Catholic separate schools would necessarily transfer to private schools. Assuming approximately half did, then a little over two-thirds $(66.8 \%)$ of private school students would be attending a religiously oriented private school, a smaller proportion than in the US.

Religious schools included in the "Other" category in Table 3 are primarily non-Catholic Christian. The US NCES report lists enrollments for 25 non-Roman Catholic Christian religious orientations, of which only the imprecise "Christian (unspecified)" category accounted for more than ten percent of private schools (12\% with $11.9 \%$ of enrollment) in 2013/14 (Broughman \& Swaim, 2016, Table 2). Jewish schools accounted for 2.8 percent of all US private schools and 5.1 percent of enrollment, while Islamic schools constituted only 0.9 percent of private schools and 0.9 percent of enrollment. In Canada, Allison, Hasan, and Van Pelt (2016, Tables 4 \& 5) classified 30.1 percent of private schools enrolling 21.8 percent of private school students as "Other Christian," many of which belonged to a Protestant church or community. Proportionally, there were five times as many Islamic (4.9\%) and somewhat less than twice as many Jewish (4.5\%) private schools in Canada as in the US. The Islamic schools accounted for 4.4 percent of Canadian private school enrollments, the Jewish schools 5.2 percent. When compared to the pertinent statistics in Table 1, it appears that substantially higher proportions of both Jewish and Muslim parents in both countries choose to enroll their children in private schools than do adherents of other faiths.

A little more than half (51.4\%) of Canadian private schools catering to a similar proportion (51.7\%) of private school students had a secular rather than a religious orientation. The corresponding proportions of US private schools were much lower, with only 31.3 percent of schools enrolling 21.3 percent of students being classified as Nonsectarian in the Broughman \& Swaim report (NCES 2016, Table 2). Nonreligious private schools in both countries encompass a rich variety of educational foci and emphases including differing instructional philosophies, specialized purposes and programs designed to meet client 
needs. Ranging from military academies to classical academies, from specialized arts and performance schools to Waldorf, STEM programs and beyond, these schools defy easy classification and comparison. Table 3 singles out two special foci of interest: Montessori and special education schools. Each country contains roughly similar proportions of each type of private school, but on average Canadian Montessori schools enroll more than twice as many students as do Montessori private schools in the US, maintaining the size differential between private schools in the two countries noted earlier. Given that public schools in both Canada and the USA are required to accommodate special needs students, the roughly similar proportions of special education private schools enrolling similar proportions of students in the two countries raises interesting questions about the kinds of disabilities that may be better served through markets than mandates.

The NCES survey classified the location of US private schools by levels of urbanicity that do not map cleanly on to the Statistics Canada hierarchy of population centers used in the Fraser Institute study. The findings reported in those studies have been collapsed into the three categories shown in Table 3 which span the urban-rural continuum in a roughly comparable manner. The parallel distributions are striking, especially with regard to the 67.6 percent of US private schools (and the 83.1 percent of their students) and the 68.9 percent of Canadian private schools (and 82.4 percent of their students) located in urban and suburban centers.

Private schools are naturally distributed across each nation in conformity with the population patterns discussed earlier. The NCES survey found that in 2013/14, 29 percent of America's 30,619 private schools were located in the four states of California (10.1\%), Pennsylvania (6.9\%), New York (5.6\%) or Florida (6.4\%) (Broughman \& Swaim, 2016, Table 15). These four states accounted for almost a third $(31.6 \%)$ of all private school students in the United States. The three states with the fewest private schools were Wyoming $(\mathrm{N}=40,0.12 \%)$, North Dakota $(\mathrm{N}=50,0.14 \%)$ and Alaska $(\mathrm{N}=50,0.14 \%)$.

In 2013/14, half of Canada's private schools (49.3\%) were located in the most populous province of Ontario (954 schools). With 340 (17.6\%) private schools, British Columbia ranked second and Quebec third with $285(14.7 \%)$ private schools. Taken together, the four Atlantic provinces were home to just 59 private schools, representing three percent of the national total. When enrollments are considered, the relative positions change for the highest ranks. Quebec had more students attending a private school than any other province, accounting for a full third (33.4\%) of national private school enrollments. Ontario followed with 31.7 percent, followed by British Columbia $(20.4 \%)$ and then, in a more distant fourth position, Alberta (7.6\%). Between them, these four provinces accounted for 93 percent of all private school students in Canada in 2013/14. The two largest provinces of Ontario and Quebec enrolled almost two-thirds (65.1\%) of all private school students in Canada (Allison, Hasan \& Van Pelt, 2016, Table 1).

Turning to the findings from the 2015 PISA surveys of private schools with 15-year old students, the far lower proportion of fully certified teachers in US private schools $(65.3 \%)$ compared to US public schools $(94.0 \%$, Table 2) is remarkable and in stark contrast to the 90 percent level in Canadian private schools, which is close to the 95.2 percent level in Canadian public schools (Table 2). Comparable OECD means are 78.3 percent $(S E=1.4)$ for private schools and 84.5 percent $(S E=0.4)$ for public schools. By itself a lower level of fully certificated teachers in non-government schools is unremarkable given the wider range of philosophical and pedagogic expertise expected across the full universe of private schools. Still, the substantial gap between the proportion of certificated teachers in US and Canadian private schools is most readily explained by the effect of regulations that must be satisfied to qualify for government funding in some Canadian provinces.

American private schools stand out once more as having notably smaller average class sizes (20.3, $S E=2.0$ ) in schools with 15 year olds. In this case, the mean class size in US private schools is not only well below the Canadian average of $28.5, S E=1.0$ ), but also markedly smaller than comparable public school class sizes in either country. The Canadian average class size in private schools enrolling 15 year olds is reported as being larger than those in public schools on either side of the border, as well as well beyond the margins of the respective standard errors. This is inconsistent with the OECD averages which show public school class sizes $(26.0, S E=0.1)$ as larger than those in private schools $(25.2, S E=0.3)$, suggesting the Canadian data may have been affected by a sampling or measurement error. There is much 
less variability on the measure of instructional hours. Once again US private schools stand out with a higher average hours of instruction per week $(28.9, S E=0.6)$ than either Canadian private schools (27.0, $S E=0.4$ ) or public schools in either country (Table 2). In this case, US private schools comfortably exceed the OECD average of 27.4 instructional hours per week, while Canadian private schools fall slightly below the OECD mean.

The autonomy gap between Canadian and US public schools noted earlier is also evident for private schools, but with the scores transposed upward, indicating higher levels of school autonomy for private compared to public schools in both countries, as would be expected, given the self-governing nature of private schools. Yet, while Canadian private schools enrolling 15 year olds scored significantly higher on the autonomy index $(\mathrm{M}=78.4, S E=5.9)$ than did Canada's public schools $(M=64.0, S E=0.79)$, they fell far below the mean score of $95.6(S E=2.9)$ reported for US private schools. This is significantly above the OECD average score of $86.7(S E=0.6)$ but still below private schools in the United Kingdom $(M=99.6$, $S E=0.2$ ), which had the highest autonomy score of all 32 OECD counties considered. US private schools ranked $7^{\text {th }}$, while Canadian private schools ranked $25^{\text {th }}$ on the school autonomy index.

\section{FUNDING}

School choice policies which do not remove onerous financial barriers to participation betray their rationale. Most US states and half of the Canadian provinces have adopted policies allocating public funds to support various school choice programs, but these policies differ in significant ways.

Five Canadian provinces directly fund qualifying private schools. These are, in order of population, Quebec, British Columbia, Alberta, Manitoba and Saskatchewan. In addition, Alberta, British Columbia, Quebec and Manitoba encourage choice within their public systems through open boundary policies. Alberta has also authorized a small number of charter schools, the only province to do so. Several minor funding provisions exist in the other five provinces, such as Nova Scotia's arrangement with several private schools to serve special needs students, but in general private schools in all Atlantic provinces and in Ontario do not receive government funding, and none of these provinces allows charter schools or funds voucher or similar programs. Ontario briefly flirted with a tax-credit program from 2001-2003, but this ground-breaking initiative was killed by a newly elected socialist government fulfilling its campaign promise to "protect public education" (Van Pelt, 2015).

Funding varies across the five funding provinces. None offer funding toward the purchase or construction of capital assets. Funding is typically calculated as a percentage of the amount given to the local public school district and is usually paid directly to qualifying private schools on a per student basis. Rates of support vary from a minimum of 35 percent for Group 2 schools in British Columbia to a maximum of 80 percent for associate schools in Saskatchewan. Of the 922 private schools in the five funding provinces in 2013/14, $646(70 \%)$ were funded at 50 percent or more of the appropriate per pupil public school amount, qualifying them to be recognized as government dependent private schools as defined by the OECD. Within Canada as a whole, a third (33.4\%) of private schools enrolling half (49.5\%) of all private school students satisfied the OECD definition of government dependent institutions in 2013/14 (Allison, Hasan \& Van Pelt, 2016, Tables B5 \& B6).

Largely because of so-called "Blaine Amendments" in state constitutions that prohibit using tax revenue to support religious schools, no US states fund private schools directly as is done in Canada. In place of such direct funding, $31(61 \%)$ states have enacted one or more programs that either transfer funds to eligible households or intermediary granting organizations, or which indirectly fund private schools through voucher or scholarship programs. Drawing on the Freidman Foundation website (Ed Choice, 2016), a total of 61 distinct programs were offered by these 31 states in late 2016, $26(42.6 \%)$ of which were classified as voucher/scholarship programs, 21 (34.4\%) as tax-credit scholarships, $9(14.7 \%)$ as individual tax-credit/deduction programs and $5(8.2 \%)$ as education savings accounts. Eighteen $(30 \%)$ of these programs were targeted at students with special needs and at least $12(20 \%)$ were at least partially targeted at low income households. For the programs for which estimates were available, the average per pupil funding provided is roughly fifty percent of public school funding in the state concerned, but with 
substantial variation around the mean. Participation data are incomplete, but we estimate some 940,000 students may benefit from these programs, which is 38 percent of private school enrollments in the 31 jurisdictions concerned, and 20.5 percent of US private school enrollments as a whole.

As discussed further by Bosetti, Brown, Hasan \& Van Pelt (2015), the greatest progress in school choice has come from the charter school revolution that has swept the US and other countries, but hardly touched Canada. From 1991 when Minnesota first adopted charter school legislation until the time of writing when a total of 43 US states plus the District of Columbia have authorized charter schools, only one Canadian province, Alberta, has done so. Moreover, Alberta's 1994 legislation capped the number of charter schools that could be approved at 15 . There are currently 13 charters in operation in Alberta, some with multiple campuses. Total 2013/14 enrollment was 8,732 students. This compares to a total of 6,465 US charter schools in 2013/14 enrolling 2,519,065 students (NCES 2015e, Table 216.20). This is more than 5.0 percent of total US public school enrollment, and equal to more than half $(55.1 \%)$ of US private school enrollment.

From zero to 2.5 million students in 23 years is truly a revolution. Those students did not only migrate from other public schools, but from private schools also. Indeed, offered a choice between a fee charging independent school and a government funded almost-independent school, many parents will likely opt for the latter, especially if they are willing to participate in governing activities or volunteer in other ways. This would seem to provide the best explanation for the decline in US private school enrollments over the past two decades.

\section{FIGURE 1}

\section{SELECTED CANADIAN AND US ENROLLMENTS AS PERCENTAGES OF NATIONAL ENROLLMENTS}

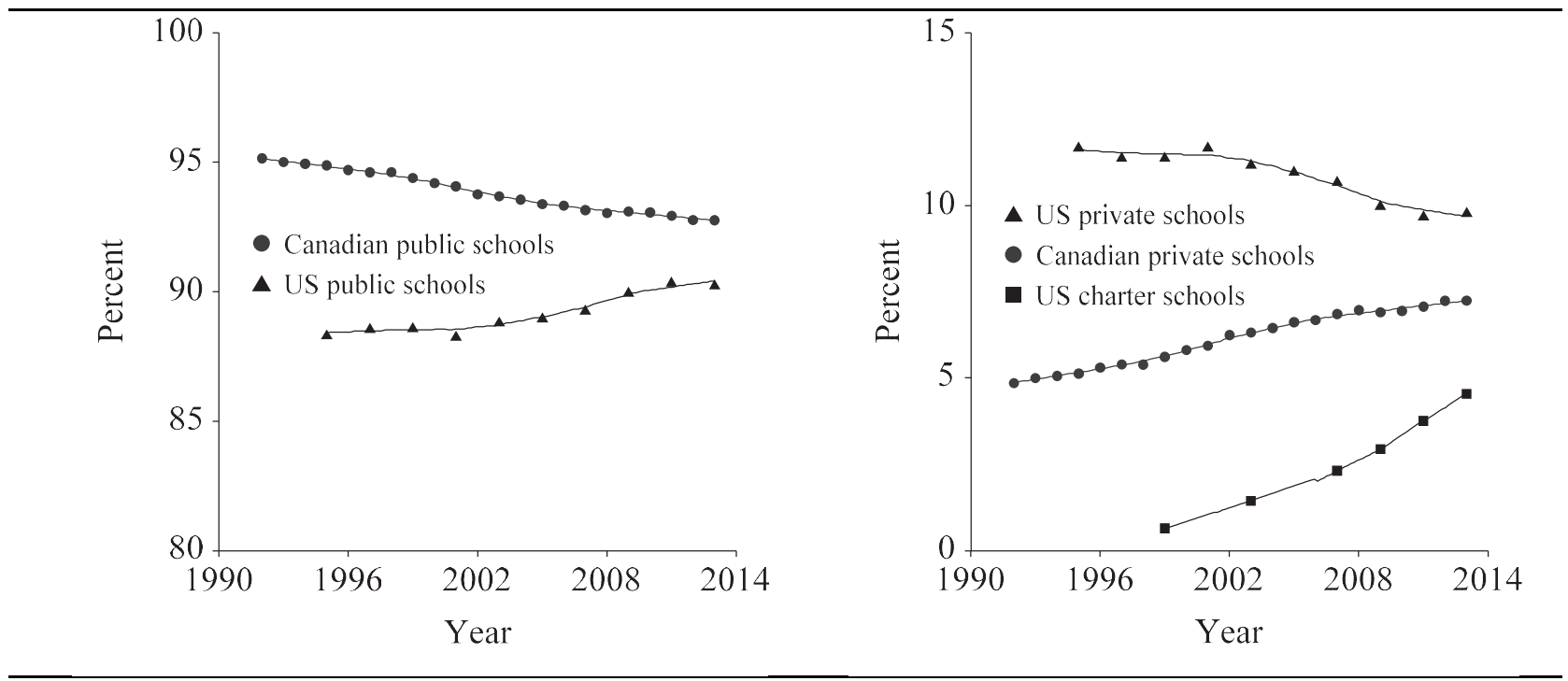

Sources. Canada percentages for 2000-2013 calculated from Van Pelt et al. (2015) and for 1992-2000 from unpublished data compiled by Brown (2015); US data calculated from NCES 2016a, 2016d \& 2016e.

Figure 1 tells the tale. The left panel shows how Canadian public schools have enrolled a steadily decreasing share of all students over the past two decades while US public enrollments have been inching up. These contrary patterns reflect national immigration and fertility statistics discussed earlier (Table 1), but have also been affected by school choice. As shown in the right side panel, Canadian private schools have been steadily recruiting a growing share of total enrollments, increasing from 5 percent of total enrollments in 1993 to 7.2 percent in 2013. Growth has been robust in all five funding provinces but also in Ontario and, to a lesser degree, Nova Scotia. In contrast, US private schools have attracted a declining share of enrollments over these two decades, decreasing from an 11.7 percent share in 1995 to 9.8 percent 
in 2013. The graph also shows how the explosion of US charter schools has generated a steeply increasing share of total enrollments, which will include migration from private-independent schools to this form of public school.

\section{DISCUSSION}

Scholars, opinion formers and politicians often look to policies and practices in other countries for ideas to guide reform in their own. Much policy borrowing has occurred between Canada and the USA, with the flow of imported ideas concerning education being primarily from the south to the north, as might be expected given the substantial disparity in population, which is mirrored in the relative capacities of their education research and development institutions. This pattern has been maintained with the infiltration of basic ideas and ideals concerning school choice. What policy implications might flow from the comparisons drawn in the preceding pages? At least three areas of interest and potential action present themselves: whether to fund for diversity or need, the charter challenge, and the perennial problem of balancing central authority with local initiative.

Half of Canada's provinces partially fund qualifying private schools through direct transfers, including religious schools. This is not accepted in the US, where legal rulings require states to channel financial support for religious schools through households or acceptable intermediary organizations. The Canadian approach, which is also widely used in other OECD countries, could be considered a more robust way of supporting school choice in that it can provide more stable support for religious and secular schools, and thus potentially more varied forms of education. But as implied by the OECD category of "government dependent" private schools, defined as those receiving more than fifty percent of their operating costs from government, this approach opens doors to closer monitoring, intervention and even limitation, which will impede diversity and limit choice. In contrast, the US approach facilitates targeting of selected students and households to compensate for disability and disadvantage, but this can also limit choice by favoring some interests over others. The challenge would seem to lie in how to best foster choice while compensating for disadvantage within a justified accountability framework. The newer education savings accounts emerging in the US may prove the best option if they continue to survive the gauntlet of escalating court challenges, which looks likely under the new administration. This approach may be worth championing in Canada, both in provinces that do not currently finance private education, and as an experimental alternative in those that do.

If charter schools continue to displace private schools in the US this also threatens to limit choice by replacing schools founded on and committed to particular educational purposes with formally free schools pursuing negotiated goals within legal frameworks promoting, or at least being seen as compatible with, government goals, policies and priorities. In this sense, charter and similar schools are, in effect, state franchises operated by quasi-private project managers in a controlled market, rather than private schools per se. Their great attraction lies in how they circumvent the stultifying political bureaucracies spawned by school districts. But when charter schools are not sustained by committed communities of parents and benefactors, management by third party agencies can open doors to other forms of maladministration, risking the educational integrity of schools. From this perspective the challenges become not just how to ameliorate financial impediments to school choice, but also how to design policies that will foster and sustain supportive communities of parents and others committed to the continuing success of schools which they see as belonging to them and serving their interests. Such strong social supports are often a feature of religiously defined schools, supporting the emergent interest in religious charter schools (Carr \& Decker, 2015; Hillman, 2008).

As ever, the keys to choice or constraint will be in the written details, in the language of enabling legislation and specific school charters. Again, the challenge would seem to lie in how best to balance language that empowers choice against that which satisfies just and justifiable expectations for accountability. There is much opportunity here for qualitative analyses of relationships between regulatory language and school experiences and outcomes that could guide reviews of current practices and development of future policies (e.g. Gibson, 2016). Such work should give attention to the challenges 
of how to build and sustain strong, supportive communities. Continued attention to the legal and logistical challenges of religious private schools also seems warranted. In the meantime, it is surely time for more Canadian provinces to initiate policy dialogues around the relative merits of charter, private and other hybrid schools (Bosetti, 2004).

These considerations refocus attention on the enduring issues surrounding the appropriate role of government in education. Canada and the US provide contrasting-indeed, often contradictoryexamples of some key options. Both are federal states, but the respective roles of their central governments could hardly be more different. Still, given their national interests, both have obligations to protect and promote the welfare of citizens, including households with school-aged children. In this respect, there would seem to be a prima facie case for both national governments to become more involved in upholding parents' rights to choose their children's education, and in facilitating their ability to do so. Canada's federal government currently allows a few minor education tax deductions that benefit households with children attending private schools. While it would face strong political opposition, such tax deductions could be expanded to specifically assist low-income households to invest in education programs of their choice. This could also be a propitious time for the US government to consider similar programs by reallocating money spent on the more intrusive federal programs affecting public schools.

One of the unexpected findings emerging from this analysis was the autonomy gap between Canadian and US schools, both public and private. There are concerns around the questionnaire items used to generate these scores and they are limited to schools enrolling 15 year old pupils but, even so, once the standard errors are figured-in, the Canadian private school mean $(78.4 \%)$ was statistically equivalent to the US public school mean (80.1) as well as significantly lower than the US private school mean (95.6\%). Moreover, students in the sample of Canadian public and private schools participating in the study outscored their US counterparts on the 2015 PISA tests, as well as those in earlier years. Greater school autonomy is widely viewed as contributing to adaptability and effectiveness, and thus these findings appear counter-intuitive. Still, despite their influence, the PISA scores are but one measure of student achievement and cannot capture the overall educational experiences provided by a school, while the autonomy scores attempt to represent a complex set of dynamic interactions with a single value. Much more work needs to be done here, both in interpreting the available PISA autonomy data and refining and improving measures of discretionary autonomy in schools that are comparable across private, public and hybrid types. One point of pertinent interest from the analysis reported here concerns the relative sizes and grade ranges of public and private schools. Private schools were smaller on average in the US than Canada, which may accord US private school heads and teachers greater autonomy than their Canadian counterparts. This disparity will be magnified by the need to conform to required provincial standards in Canadian government-dependent private schools. Exploring these and related possibilities is one of the paths to better understanding relative levels of autonomy, discretion, performance and accountability in schools.

What does all this imply for the equifinality principle? Some consistent structural similarities did emerge between private schools in the two countries. On average, private schools are smaller (enroll fewer students) than public schools and, despite the differences noted above, private schools had higher average scores on the autonomy measure than did public schools in both countries. Further, the proportions of Montessori and special education private schools in both countries were remarkably similar, as was the distribution of private schools across the urban-rural continuum, even though the geographical settlement patterns are quite different in the two countries. In contrast, notable differences are evident in the number of religious private schools and the proportions of students enrolled in these, and in the approaches taken to funding private schools. Constitutional and social legacies of the different religious histories in the two counties are influential here, creating environmental constraints forcing differences between the forms taken by religious schools and funding policies. 


\section{CONCLUSION}

To return to the problem of knowing about schools with which we began, while private schools in Canada and America may not enroll many students named Chatsworth Osborne, Jr., and their supporters undoubtedly have less money than God, a casual observer could probably easily distinguish a private education venture from a neighborhood public school. But knowing about individual schools does not extend to knowing about all. The descriptive statistics consulted and compared in this paper offer what we believe to be a valuable comparative overview of private schools in each country. While admittedly limited, the account given could not have been attempted prior to the compilation of statistics undertaken in the Fraser Institute study of Canadian schools which, in turn, was prompted by the continuing surveys of US private schools undertaken by the National Center for Education Statistics. Further, important aspects of the analysis drew on statistics extracted from the more recent trans-national PISA reports. The importance of such data sources in facilitating research into schools of choice cannot be underestimated.

\section{ENDNOTE}

1. Principals were asked to indicate which actors had responsibility for twelve tasks distributed across the governance areas of resources, curriculum, discipline, assessment and admissions. Specific tasks included selecting teachers, firing teachers, formulating the school budget and selecting curriculum content. Principals could choose between five levels of hierarchical decision making: teachers, principals, "school governing board, local/regional or national authorities" (See OECD 2016c, Figure II .4.2, p. 113). The failure to explicitly distinguish between school level governing bodies responsible for a single school and school boards and their bureaucracies responsible for networks of schools is a weakness that distorts comparable results for public and private schools.

\section{REFERENCES}

Allison, D. J. (2015). School choice in Canada: Diversity along the wild-domesticated continuum. Journal of School Choice: International Research and Reform 9: 282-309. http://dx.doi.org/10.1080/15582159.2015.1029412

Allison, D. J., \& Van Pelt, D. N.. (2012). Canada. In C. Glenn \& J. De Groof (Eds.), Balancing freedom, autonomy and accountability in education (Vol. 3, pp. 79-146). Oisterwijk, Netherlands: Wolf Legal Publishers.

Allison, D. J., Hasan, S. \& Van Pelt, D. N., (2015). A diverse landscape: Independent schools in Canada. Fraser Institute. < https://www.fraserinstitute.org/sites/ >

Bertalanffy, L. (1969). General system theory: Foundations, development, applications. New York: George Braziller.

Bosetti, L. (2004). Determinants of school choice: Understanding how parents choose elementary schools in Alberta. Journal of Education Policy, v19 n4 p387-405 Jan 2004.

Bosetti, L., Brown, B., Hasan, S. \& Van Pelt, D. N. (2015). A primer on charter schools. Fraser Institute. $<$ http://www.fraserinstitute.org $>$

Broughman, S. P., \& Swaim, N.L. (2016). Characteristics of Private Schools in the United States: Results From the 2013-14 Private School Universe Survey (NCES 2016-243). U.S. Department of

Education. Washington, DC: National Center for Education Statistics.

http://nces.ed.gov/pubsearch.

Brown, B. (2015). Unpublished Canadian school choice data compiled for Barbara Mitchell Centre for Improvement in Education at the Fraser Institute, Vancouver, BC.

Canadian Education Association (2015). Directory. http://handbook.cea-ace.ca

Carr, K. A., \& Decker, J. (2015). Clarifying the public-private line: Legal and policy guidance for catholic-affiliated charter schools. Journal of Catholic Education, 18(2), 163-184. doi:http://dx.doi.org/10.15365/joce.1802092015 
Clemens, J. Palacios, M., Loyer, J., \& Fathers, F. (2013). Measuring Choice and Competition in Canadian Education: An Update on School Choice in Canada. Fraser Institute.

$<$ http://www.fraserinstitute.org $>$.

CIA. (2016). Factbook. < https://www.cia.gov/library/publications/the-world-factbook >

Council of Ministers of Education, Canada. (2016) Education in Canada: An Overview. Ottawa. http://www.cmec.ca/299/Education-in-Canada-An-Overview/index.html\#02

Credit Suisse AG. (2016). Global wealth databook, 2016. Credit Suisse AG Research Institute. Zurich.

Cutler, D. (2015). The Private-School Stigma. The Atlantic. January. < http://www.theatlantic.com $>$

Ed Choice, (2016). < https://www.edchoice.org/ >

Gibson, Mark T. (2016). Sponsored academy school principals in England: Autonomous leaders or sponsor conduits? International Studies in Educational Administration, 44 (2).

Hillman, B. (2008). Is there a place for religious charter schools? The Yale Law Journal, 118(3), 554-599. doi: $10.2307 / 20454720$

NCES, (2014). Digest of educational statistics, Common core of data (CCD), ""Public Elementary/Secondary School Universe Survey," 1982-83 through 2012-13," Table 216.45. US Department of Education, National Center for Education Statistics. https://nces.ed.gov/programs/digest/

NCES. (2015a). Digest of educational statistics, 2015. Table 203.40. Enrollment in public elementary and secondary schools, by level, grade, and state or jurisdiction: Fall 2013. U.S. Department of Education, National Center for Education Statistics, Common Core of Data (CCD), https://nces.ed.gov/programs/digest/d15/tables/dt15 203.40.asp

NCES. (2015b). Digest of educational statistics, 2015. Table 214.20. Number and percentage distribution of regular public school districts and students, by enrollment size of district: Selected years, 197980 through 2013-14. U.S. Department of Education, National Center for Education Statistics, Common Core of Data (CCD), https://nces.ed.gov/programs/digest/d15/tables/dt15 214.20.asp

NCES. (2015c). Digest of educational statistics, 2015. Table 216.10. Public elementary and secondary schools, by level of school: Selected years, 1967-68 through 2013-14. US Department of Education, National Center for Education Statistics. Common core of data (CCD) "Public https://nces.ed.gov/programs/digest/d15/tables/dt15 216.10.asp

NCES. (2015d). Digest of educational statistics, 2015. Table 205.10. Private elementary and secondary school enrollment and private enrollment as a percentage of total enrollment in public and private schools, by region and grade level: Selected years, fall 1995 through fall 2013. US Department of Education, National Center for Education Statistics. Common core of data (CCD) https://nces.ed.gov/programs/digest/d15/tables/dt15 205.10.asp

NCES. (2015e). Digest of educational statistics, 2015. Table 216.20. Number and enrollment of public elementary and secondary schools, by school level, type, and charter and magnet status: Selected years, 1990-91 through 2013-14. US Department of Education, National Center for Education Statistics. Common core of data (CCD). https://nces.ed.gov/programs/digest/d15/tables/dt15 216.90.asp

OECD Data, (2016a). Income inequality (indicator). doi: 10.1787/459aa7f1-en

OECD Data, (2016b). Tax revenue (indicator). doi: 10.1787/d98b8cf5-en.

OECD (2016a), Education at a Glance 2016: OECD Indicators, OECD Publishing, Paris. DOI: http://dx.doi.org/10.1787/eag-2016-en

OECD (2016b), PISA 2015 Results (Volume I): Excellence and Equity in Education, PISA, OECD Publishing, Paris. http://dx.doi.org/10.1787/9789264266490-en

OECD (2016c), PISA 2015 Results (Volume II): Policies and Practices for Successful Schools, PISA, OECD Publishing, Paris. http://dx.doi.org/10.1787/9789264267510-en

OECD (2016d). Country note - Key findings from Pisa 2015 for the United States, PISA, OECD Publishing, Paris. http://www.oecd.org/pisa/keyfindings/PISA-2012-results-US.pdf

OECD (2012), Public and Private Schools: How Management and Funding Relate to their Socioeconomic Profile, OECD Publishing. http://dx.doi.org/10.1787/9789264175006-en 
Ontario, (2016). Ontario public schools enrolment dataset, 2013-14 academic year. < https://www.ontario.ca/data $>$

Pew Research Center. (2015). America's changing religious landscape. $<\underline{\text { http: } / / w w w . p e w f o r u m . o r g ~}>$

Ryan, C. (2013). Language use in the United States. US Census Bureau, US Department of Commerce. < https://www.census.gov/prod/2013pubs/acs-22.pdf >

Statistics Canada (2015a). 2011 census of population program, Table 4 Language spoken most often at home, Canada, Quebec, Canada outside Quebec, 2006 and 2011.< http://www12.statcan.gc.ca/census-recensement/2011/as-sa/98-314-x/2011001/tbl/tbl4-eng.cfm

Statistics Canada (2015b). Cansim Table 477-0025. Number of students in regular programs for youth, public elementary and secondary schools, by grade and sex, Canada, provinces and territories. $<$ http://www5.statcan.gc.ca/cansim $>$

Statistics Canada (2017). Immigration and ethnocultural diversity highlight tables. Visible minority (total - population by visible minority), both sexes, age (total), Canada, provinces and territories, 2016 Census - 25\% Sample data. http://www12.statcan.gc.ca/census-recensement/2016/dp-pd/hltfst $/ \mathrm{imm} /$ Table.cfm?Lang $=\mathrm{E} \& \mathrm{~T}=41 \& \mathrm{Geo}=00 \& \mathrm{SP}=1 \& \mathrm{vismin}=1 \& \mathrm{age}=1 \& \mathrm{sex}=1$

US Census Bureau (2016). Quick facts. $<\underline{\text { http://www.census.gov/quickfacts }}>$

Van Pelt, Michael (2015, May 26). How to break Ontario's monopoly on education. Globe and Mail http://www.theglobeandmail.com

Van Pelt, D.A., Allison, P.A., \& Allison, D.J. (May 2007). Ontario's Private Schools: Who Chooses Them and Why? Fraser Institute. Retrieved from: https://www.fraserinstitute.org/sites/default/files/OntariosPrivateSchools.pdf

Van Pelt, D. N., Clemens, J., Palacios, M., \& Brown, B. (2015). Where our students are educated: Measuring student enrolment in Canada. Barbara Mitchell Centre for Improvement in Education. Fraser Institute, Vancouver, BC < https://www.fraserinstitute.org/sites/ $>$

World Bank, (2017). Indicators. $<\underline{\text { http://data.worldbank.org }>}$ 